\title{
Katherine Southwood
}

\section{The Impact of the Second and Third-Generation Returnees as a Model for Understanding the Post-Exilic Context}

By using the framework of return migration, and its common effects on ethnic identity, as a heuristic analytical tool through which to achieve a more sophisticated level of dialogue with Ezra's intermarriage crisis, it may be possible to address the return from exile with fresh insight. As will be demonstrated, it seems that once religious identity is factored into the equation, migration becomes a powerful variable which has a drastic impact on the constructions of ethnic identities.

Before examining and analysing the evidence at stake, some brief comments regarding the choice of applying a social-scientific method to the text are necessary. Although this issue has been discussed in detail elsewhere, ${ }^{1}$ it is nevertheless important to re-iterate a number of key points which are often overlooked, forgotten, or simply misunderstood regarding the use of the social sciences for understanding the exilic and post-exilic contexts and for understanding the biblical text. First, the use of the later-generations return model is not being applied to the material as if it were ontologically 'true'. ${ }^{2}$ Rather, material taken from a continually growing field of research into generations of returnees is being applied in order to gain a new perspective on the material and to assess the extent to which the model assists us in this task. We are not attempting to validate the model

\footnotetext{
1 A vast array of material exists concerning this discussion. Much of it is referenced in Katherine Southwood, Ethnicity and the Mixed Marriage Crisis in Ezra 9-10: An Anthropological Approach (Oxford Theological Monographs; Oxford: Oxford University Press, 2012), 9-15; and Katherine Southwood, 'Ethnicity and Ethnography', in The Oxford Encyclopedia of the Bible and Ethics (ed. Robert L. Brawley; Oxford: Oxford University Press, 2014), 238-243. For a general overview, refer to Philip F. Esler (ed.), Ancient Israel: The Old Testament in Its Social Context (Minneapolis: Fortress Press, 2006) and to Robert R. Wilson, 'Reflections on Social-Scientific Criticism', in Method Matters: Essays on the Interpretation of the Hebrew Bible in Honor of David L. Petersen (SBLRBS 56; ed. Joel M. LeMon and Kent H. Richards; Atlanta: Society of Biblical Literature, 2009), 505-522. Also, for an excellent example of the application of the approach refer to Philip F. Esler, Sex, Wives, and Warriors: Reading Biblical Narrative with its Ancient Audience (Eugene, OR: Cascade Books, 2011).
}

2 Refer to note 21 for a discussion of the problems concerning the term 'generation'.

Katherine Southwood: University of Oxford 
itself, neither is application of the model an attempt to 'validate' some reconstructed version of 'the Bible's historicity'. Second, we are not forcing the biblical and extra-biblical evidence to fit into the model's schema, nor is the material concerning later generations of migrants chosen to mirror the biblical material. Instead, the aim of using this model is as a heuristic analytical tool with which to discern any patterns within the evidence that may before have gone unnoticed with the use of traditional methods.

For example, rather than imagining the 'exiles in Babylon' the use of modern studies shows us the complexity of exile. It is very unlikely that all exiles would have been in the same place and still less likely that they all returned at once. Instead, we should consider the many different contexts of exile. Most notably, we realise that not all communities in exile would have acculturated at the same pace; those who were in rural settlements may, in fact, have resisted assimilation. ${ }^{3}$ Likewise, careless use of terms drawn from the social sciences are clarified and sharpened through greater reference to the on-going work of ethnographers, anthropologists, and sociologists. Rather than using intuitive, value-laden, language such as 'actual foreigners', reference to such research allows us not to take such terminology for granted, but to ask more perceptive questions such as 'how might Judean ethnic identity be understood? In what sense is Judean ethnic identity measurable for later generations in exile'? Effectively, by using models drawn from a variety of modern studies we are attempting to avoid projecting ethnocentric and anachronistic perspectives on to the text. ${ }^{4}$ Hence, what we are trying to

3 Liisa H. Malkki, Purity and Exile: Violence, Memory and National Cosmology among Hutu Refugees in Tanzania (Chicago: Chicago University Press, 1995); Southwood, Ethnicity, 41-48. Note that the later Murašû documents from Nippur show individuals with Yahwistic names who are reasonably well-assimilated into the economic system as smallholders, petty officials, tax-collectors and witnesses. Similarly, the later documents from Elephantine, despite a plea to the Jerusalem temple, never actually allude to any desire to move to Yehud. Therefore, it is reasonable to suggest that not all people with Yahwistic beliefs and/or culture maintained a desire to 'return' and that different experiences of exile existed.

4 The criticism of 'anachronism' which is often levelled against social scientific models is one of the main things such models actually aim to avoid. Rather than attempting to force the biblical text and ancient evidence into any one model, a model is instead constructed carefully through compiling evidence which is taken from the accumulation of data. The aim is, therefore, to reach a culturally consistent model or set of analytical questions through which to analyse the biblical data. It is important not to treat such models as definitive, but instead to attempt to think of them as offering plausible suggestions which inform our broader understanding. It must be acknowledged that the two sets of data being compared are very different. However, anthropologists on fieldwork research sometimes face similar challenges to the biblical scholar using anthropology in terms of a mismatch of the data available and the questions being asked. For example, the 
achieve is a guide designed to direct us to the most pertinent questions regarding the data - biblical and extra-biblical - which we have. That is, through increased use of material within subjects such as, in this case, social anthropology, we are looking for the connections between ideas and concepts and for the increased awareness, precision, and comprehension of the analytical language which we apply to the data.

It takes little more than a glance through the literature to recognize the lack of terminological clarity regarding 'return migration'; some of the terms used to describe the phenomena include repatriation, counter-stream migration, reflex migration, retro-migration, and U-turn migration. Perhaps this lack of concrete definition mirrors the problematic nature of the term 'return' itself. The literature on, what will for convenience's sake be loosely termed, 'return migration' occurs within the broader parameters of research into ethnicity, a phenomenon which is itself contentious and difficult to define. Thus against the context of ethnicity, migrations and return migrations have a vast impact on migrants, and those who do not move away. ${ }^{5}$ The problematic nature of 'return' migration is intricately connected to the complexities surrounding the notion of a homeland. In the imaginations of many Diaspora communities, ${ }^{6}$ the homeland not only con-

emic interpretation of a behaviour as tradition, or custom, may differ considerably from the etic questions about how, and in what context, certain behaviours emerged. I have discussed this problem at length elsewhere (Southwood Ethnicity, 9-16).

5 Barth's seminal study, which was brutally challenged by Cohen, provoked a renewed interest within the field of social anthropology into ethnicity. Barth illustrates how ethnic identities are experienced the strongest (as both dividing and uniting factors) in times of threat; see Fredrick Barth, Ethnic Groups and Boundaries: The Social Organization of Culture Difference (Oslo: Universitetsforlaget, 1969) and Anthony P. Cohen, The Symbolic Construction of Community (Key Ideas; Chichester: Ellis Horwood, 1985). However, the term ethnic identity is 'so vague, and so variously used' (Cohen, The Symbolic Construction, 107) that it is to some extent 'still on the move' (Nathan Glazer and Daniel P. Moynihan, eds., Ethnicity: Theory and Experience [London: Harvard University Press, 1975], 1), hence referring to 'ethnic movements' rather than identities may be more practical (Marcus Banks, Ethnicity: Anthropological Constructions [London: Routledge, 1996], 136). Although there is not enough space to sufficiently address the complexities of the vast literature concerning ethnicity, it is worth acknowledging that debates within social anthropology and sociology regarding ethnicity can be divided into various methodological camps, most prominently, primordialism and instrumentalism. For further discussion, refer to Southwood, Ethnicity, 19-72.

6 Defining the term 'diaspora' is also problematic. Cohen produces a five-fold typology of the topic to include (Robin Cohen, Global Diasporas: An Introduction [London: UCL Press, 1997]): Victim diasporas (Jews, Armenians, slave diasporas); Labour diasporas (Indian indentured labour, Italians, and Filipinos); Imperial/colonial diasporas (Ancient Greek, British, Portuguese); Trade diasporas (Lebanese, Chinese); Cultural diasporas (Caribbean). A more productive way of 
tinues to be relevant, but is also imbued with a renewed level of significance for such communities. ${ }^{7}$

In her influential book, Cartographies of Diaspora, Avtar Brah illustrates the multi-local perceptions of 'home' among diasporas through underlining the difference between 'home as where one is' and home as 'where one comes from'. Home, Brah argues, is the 'lived experience of locality, its sounds and smells', yet it is also a 'mythic place of desire in the diasporic imagination ... a place of no return, even if it is possible to visit the geographical territory that is seen as the place of origin'. ${ }^{8}$ This gives way to the 'myth of home' which emerges as a result of

defining diasporas can be found through examining the priorities and ideals of Diaspora communities themselves, rather than imposing external descriptive categories on certain Diaspora communities. For example, Safran shows that diasporas are 'expatriate minority communities' whose notable characteristics include (William Safran, 'Diasporas in Modern Societies: Myths of Homeland and Return', Diaspora 1/1 [1991]: 83-84): Diasporas, or their ancestors, were dispersed, (through persecution and genocide), from a specific original centre to two or more distant, foreign locations; diasporas maintain a collective memory, which may be mythical, about their homeland; diasporas may believe that they are not fully accepted by their host country and this may lead to isolation; diasporas understand their ancestral home as their 'authentic, pure' home and as a place of eventual return; diasporas are committed to the maintenance and restoration of their homeland; the diaspora's consciousness and solidarity are importantly defined by their on-going relationship to their homeland.

7 This is unsurprising in light of some of the observations regarding the development and articulation of ethnic identity. As Harre comments, 'People typically form their identities within the context of their ethnic backgrounds and the socio-political contexts in which they are socialised. Moreover people often construct autobiographies to place themselves in the social order and seek out settings and situations for confirmation' (Rom Harre, 'Language Games and Texts of Identity', in Texts of Identity [ed. John Shotter and Kenneth J. Gergen; London: Sage, 1989], 20-35). This is also reflected in the many security risks that can be associated with the homeland, as stated in Amnesty International's journal Refugee, 'Despite the bitter memories most victims must have of their expulsion or flight, many refugees and displaced people are determined to return. Their greatest concern appears to be the security and the political situation in their home areas ....' (Amnesty International, 'Who's living in My House?': Obstacles to the Safe Return of Refugees and Internally Displaced Peoples. (Bosnia-Herzegovina) Refugee [AI Index: EUR 63/ 01/ 1997]: 4).

8 Avtar Brah, Cartographies of Diaspora: Contesting Identities (London / New York: Routledge, 1996), 192. It is important to realise at this point that the concept of a homeland is also, to some extent, ideological since it is socially constructed in the imaginations of those who perceive themselves as having been separated from it. For example, for some migrants, or indeed later generations of migrants whose parents and grandparents successfully integrate in their host societies, their new circumstances quickly become their home. This is more likely for those who have chosen, rather than been forced, to migrate. This paper uses the term homeland with the assumed context of those who perceive themselves as exiles from the land. 
the fact that the rose-tinted illusion of the homeland experience is frozen in space and time, an ossified relic of a past existence.

This longing for the mythical homeland is easily discerned through the material relating to the Babylonian exile. The place name ‘the city of Judah' (āl-Yāhūdu) is represented on cuneiform tablets referring not to Jerusalem, but to a place in Babylonia. ${ }^{9}$ This name reflects the geographic and ethnic origin of its population since onomastic examination of the tablets reveals numerous West Semitic and Yahwistic names. ${ }^{10}$ The Babylonian practice of grouping ethnic communities together may have facilitated an increased awareness of ethnicity since the custom of naming a settlement according to the origins of the exiles living there is well attested. ${ }^{11}$ However, in light of the evidence concerning return migration, it is possible that the name may also betray a degree of emotional attachment to the homeland and would also function as a constant reminder of ethnic origins. ${ }^{12}$

Alongside the epigraphic evidence, a variety of biblical texts attest the sense of ideological attachment to the pre-exilic homeland and attempts at conformity with past cultural and religious practice. Numerous examples of this sentiment occur in prophetic literature, which Blenkinsopp has aptly designated 'projections of a restored past in post disaster prophecy. ${ }^{13}$ However, the narrative within the book of Ruth may also provide an example of ethnic change in relation to the homeland. Some scholars have already noted the change for Ruth herself who, given the epithet 'the Moabite' appears not to be a returnee. For example, Lau argues that Ruth subordinates and overrides her own identity since kinship is

9 Francis Joannès and André Lemaire, 'Trois tablettes cunéiformes à onomastique ouest-sémitique', Transeuphratène 17 (1999): 17-33.

10 See Cornelia Wunsch and Laurie E. Pearce, Documents of Judean Exiles and West Semites in Babylonia in the Collection of David Sofer (CUSAS 28; Bethesda, MD: CDL Press, 2015). These studies supersede some of the details given in the preliminary, but nevertheless instructive, articles: Laurie Pearce, 'New Evidence for Judeans in Babylonia,' in Judah and Judeans in the Persian Period (ed. Manfred Oeming and Oded Lipschits; Winona Lake: Eisenbrauns, 2006), 399-411, and Laurie Pearce, “'Judean:” A Special Status in Neo-Babylonian and Achaemenid Babylonia?', in The Judeans in the Achaemenid Age: Negotiating Identity in an International Context (ed. Manfred Oeming and Oded Lipschits; Winona Lake: Eisenbrauns, 2011), 267-277.

11 Israel Eph'al, 'On the Political and Social Organization of the Jews in the Babylonian Exile' ZDMGSup 5 (1980): 106-112.

12 For a more extensive study of mirror names, refer to Dominique Charpin, 'La "toponymie en miroir” à l'époque amorrite', $R A 97$ (2003), 3-34, and see the contribution of Gauthier Tolini in the present volume.

13 Joseph Blenkinsopp, Judaism, The First Phase: The Place of Ezra and Nehemiah in the Origins of Judaism (Grand Rapids, MI: Eerdmans, 2009), 122-125. 
her priority. ${ }^{14}$ Likewise, Glover emphasizes the transformation in Ruth's ethnic identity by the end of the narrative, noting that 'Ruth's ethnic transformation is mysterious because at the last the text abandons its obsession with Ruth's ethnicity.' Indeed, Ruth is continually called a Moabite (Ruth 1:4, 22; 2:2, 6, 21; 4:5, 10). 'However, in the text's final reference, Ruth is given no ethnic identifier. She is no longer "Ruth the Moabite", neither is she "Ruth the Israelite"; rather she is simply "Ruth". ${ }^{15}$ However, attention is seldom given to the idea of, and effects of, migration within the text. At the outset, we are informed that Naomi

Wherefore she went forth out of the place where she was, and her two daughters in law with her; and they went on the way to return (לשוב) unto the land of Judah. (Ruth 1:7)

Furthermore, a few verses later, we are reminded that Naomi intends not just to travel, but to return, as the daughters-in-law claim that 'we will return (נשוב) with you' (Ruth 1:10). This is emphasized again at the end of the chapter when we are told that Naomi 'returned' and Ruth 'returned' with her (Ruth 1:22). It is interesting that when famine and death occur Naomi's reaction is to return to the homeland. Perhaps such a move can be interpreted as evidence of Naomi's perception of Bethlehem, the place to which Naomi returns, as a place of safety and refuge. However, as Matthews notes, 'Naomi faces the uncertainty on her return to Bethlehem of how to maintain control of Elimelech's property and to keep his name alive, and this may contribute to her labelling herself as "Mara" (bitter) when the women exclaim "Is this Naomi?" (1:19-20).'16 Effectively, upon return to the homeland, Naomi is perceived differently to the extent of being unrecognizable and the realization of the return leads to a new set of problems in the homeland. What is interesting about this new relationship between Naomi and Bethlehem is the effect it has on Ruth's relationship to the 'homeland'. As noted, the text makes it clear from the start that Ruth is a Moabite. However, through returning with Naomi, her mother in law, Ruth can be understood as a later-generation returnee. Although Ruth is not returning in the strict sense, she is nevertheless incorporated within Naomi's homeland community by virtue of the generations and family link between herself and Naomi.

14 Peter H. W. Lau, Identity and Ethics in the Book of Ruth: A Social Identity Approach (BZAW 416; Berlin / New York: de Gruyter, 2011).

15 Neil Glover, 'Your People, My People: An Exploration of Ethnicity in Ruth', JSOT 33 (2009): 293-313, and Katherine Southwood, 'Will Naomi’s Nation be Ruth's Nation?: Ethnic Translation as a Metaphor for Ruth's Assimilation within Judah', Humanities 3 (2014): 102-131.

16 Victor H. Matthews, 'The Determination of Social Identity in the Story of Ruth', BTB 36 (2006): 49-54, citation page 52. 
The most obvious example is Psalm 137 which not only highlights the dissonance of living in a 'foreign land' (אדמת נכר) but also centralizes the religious culture of the homeland (singing the 'songs of Yahweh'), and emphasizes remembering and not forgetting Jerusalem as the 'capital' (ראש) joy (Ps 137:1-6). ${ }^{17}$ The emotionally charged repetition of, and balance between, the polarized terms remember/forget in Hebrew may be an indication of the increased significance of the homeland.

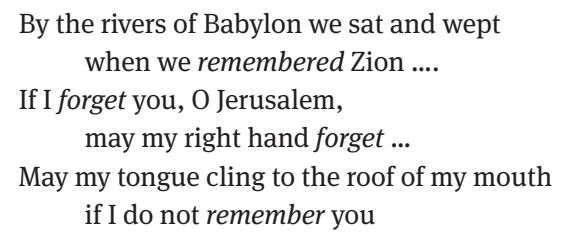

Effectively, we have a classic example of the greater symbolic significance of the homeland and the desire to move back to what may have been seen by exiles as a sort of glorious pre-exilic 'golden age'. This concept is intimately linked to the development of ethnicity through the forging of 'home-from-home' collective diasporic identities wherein the 'nation' and 'homeland' are conflated. Thus, it may be that the attempt to preserve past cultural practices - perhaps resistance to intermarriage among them - and a sense of 'homeland' despite being in exile represent the development of a stronger awareness of foreignness. ${ }^{18}$ Similarly, the representations of the experiences of exiles within later texts attest the consciousness of being 'foreign' and consequent resistance to cultural and ethnic assimilation.

However, one complication connected to the return migration model, which is particularly significant for the postexilic context, is the possibility that part of the returning population were 'ancestral return migrants' who were born in exile. To clarify, that is, the 'return' to the 'homeland' of the later generations of exiles. Of course, this concept is an oxymoron. Such so-called return migrants are not return migrants, but are born in a host society of migrant parents. Hence they are not return migrants in the strict sense, but first-time emigrants to their parents' country of origin. As a result, King nominates the category 'counter-diasporic

17 The end of verse 137:5 is missing in Hebrew: ... אם אשכחך ירושלם תשכח ימיני. Translations often insert an object, such as 'its work'.

18 It must be noted that this is not a model for all Judeans living outside Jerusalem. For example, intermarriage occurs without comment in marriage contracts from Elephantine, TAD B2.4, 2.6, 3.3, 3.6, 3.7, 3.8, 6.1, 6.2, 6.3 and 6.4. 
migration' to describe the return to the diasporic hearth of descendants of the original migrants who were scattered. According to King, the people 'returning' are the children of the original exiles, or the link can be more historically remote (return to the land of the ancient ancestors). ${ }^{19}$ If this is the case, then to what extent can we maintain that the difference between the returnee and 'stayee' populations is an intra-Jewish matter, as Smith-Christopher states in '... some of these "mixed" marriages ... were probably not "mixed" at all in any truly racial/ethnic sense of the term. ${ }^{, 20}$ Although this, in many ways, brings us back to the complex, perhaps irresolvable, question of what ethnic movements are, and how ethnicity might be defined and measured, some further research into the effects of modern ancestral return movements is clearly warranted.

One way of looking at this rather broad category of migrants is to narrow the boundaries slightly by examining research concerned with second- and third-generation migrants. ${ }^{21}$ This focus has the advantage of being slightly more

19 Russell King, 'Generalizations from the History of Return Migration', in The Mediterranean Passage: Migration and New Cultural Encounters in Southern Europe (Liverpool Studies in European Regional Cultures 9; ed. R. King; Liverpool: Liverpool University Press, 2001), 7-55.

20 Daniel L. Smith-Christopher, 'Between Ezra and Isaiah: Exclusion, Transformation and Inclusion of the "Foreigner" in Post-Exilic Biblical Theology', in Ethnicity and the Bible (Supplements to Biblical Interpretation 19; ed. Mark G. Brett; Leiden: Brill, 1996), 123; Daniel L. SmithChristopher, 'The Mixed Marriage Crisis in Ezra 9-10 and Nehemiah 13: A Study of the Sociology of the Post-exilic Judean Community', in Second Temple Studies 2: Temple and Community in the Persian Period (JSOTSup 175; ed. T. C. Eskenazi and K. H. Richards; Sheffield: Sheffield Academic Press, 1994), 257. I have discussed the problems associated with failing to distinguish between race, ethnicity, and nationalism elsewhere (Southwood, Ethnicity, 31-41). It should be noted that since ethnicity and race are socially constructed, it might be difficult to refer to a 'true' sense of the term.

21 The use of second- and third-generation migrants is chosen here because of the difficulty of defining clearly what is meant by 'generation'. There is some degree of debate about the usefulness of the very notion of "generation" as a demographic and sociological concept (Susan Eckstein, 'On Deconstructing and Reconstructing the Meaning of Immigrant Generations', in The Changing Face of Home: Transnational Lives of the Second Generation [ed. Peggy Levitt and Mary C. Waters; New York: Russell Sage Foundation, 2002], 211-215; Peter Loizos, 'Generations in Forced Migration: Towards Greater Clarity', Journal of Refugee Studies 20 [2007]: 193-209). Kertzer identifies four meanings (David I. Kertzer, 'Generation as a Sociological Problem', Annual Review of Sociology 9 [1983]: 129-149: Generation as a principle of kinship descent: here it is a relational, genealogical concept used to define patterns within the larger universe of kinship; generation as life-stage, often referring to a particular life-course segment (infancy, childhood, adolescence, adulthood, middle age, elderly etc.) or to more generalised contrasts (younger generation, older generation, college generation etc.) where there may or may not be a genealogical relation such as parent-child; generation as cohort: a set of similar-age people moving through the life-course, for instance based on a birth cohort; generation as historical period: the mean- 
relevant as a heuristic tool for building a picture of post-exilic Yehud than, for example, ancestral return movements with gaps of several centuries.

What is interesting about this research is the number of defining characteristics which mark the language and imagery connected with ancestral return movements. Initially, as Cohen points out, a strong agricultural or gardening trope is evident in the semantics and discourse of diasporas. ${ }^{22}$ Diaspora members frequently talk of 'roots', 'ancestral soil' and 'family trees' to the extent that some anthropologists, during fieldwork, have adopted this language, classifying the concept as a whole as 'roots return'.23 This indicates a special awareness of kinship at an emic level when kinship and land are very closely connected. Although an individual rather than a group example, the experience of Rebecca as recorded within King and Christou's fieldwork, is a classic example of this conceptual connection. ${ }^{24}$ Rebecca, a returnee to Greece, responds thus when quizzed about why she decided to return and what it meant for her identity:

... I'd been working all over the place and also ignored the fact that I have Greek roots ... and then it was an identity crisis of ... 'Who are you?' This is when I started to discover that it's to do with - not where I'm coming from, not where I was born - but with my ancestors. ${ }^{25}$

Thus, there is another dimension involved in the second-generation's 'return' to the 'homeland'; not only is the journey evidence of their embracing a particular

ing used by Eckstein above, where generation is linked to some historical event or to people living/moving in a particular historical period. Further problems occur when we begin to relax these definitions. For example, what about children with one immigrant parent? How do we view children brought to a host country when they are very small? Given the problematic nature of defining this term clearly, second- and third-generations are included in order to give an impressionistic portrait of the situation. Such an impressionist portrait is preferred over enforced systematization between generations, such as can be found in other nevertheless commendable studies of later generations: John J. Ahn, Exile as Forced Migrations: A Sociological, Literary, and Theological Approach on the Displacement and Resettlement of the Southern Kingdom of Judah (BZAW 417; Berlin: de Gruyter, 2011).

22 Cohen, Global Diasporas, 177-178.

23 E.g. Paul Basu, 'Route metaphors of "roots-tourism" in the Scottish Highland diaspora', in Reframing Pilgrimage: Cultures in Motion (ed. Simon Coleman and John Eade; London: Routledge, 2004), 150-174.

24 Russell King and Anastasia Christou, Cultural Geographies of Counter-Diasporic Migration: The Second Generation Returns 'Home' (Sussex Migration Working Paper 45; Sussex: University of Sussex, 2008), reprinted as 'Cultural Geographies of Counter-Diasporic Migration: Perspectives from the Study of Second-Generation "Returnees" to Greece', Population, Space and Place 16 (2010): 103-119.

25 King and Christou, Cultural Geographies, 17. The citation is not included in the reprint. 
myth of the homeland, created by their parents or grandparents, and an attempt to rediscover and reclaim its sacred sites, it is also the discovery of and search for what Blunt terms 'grounded attachment'. ${ }^{26}$ However, from the perspective of those who never left the land the roots metaphor may be interpreted as an expression of a 'darker purpose'. It becomes self-certifying and ends up being emphasized over and above the empirical facts of migration, geography and genealogy to the extent that second- and third-generation returnees often end up being overly keen to emphasize survival narratives of the ancestors.

A good illustration of this idea of roots return are the narratives relating to the lists in Ezra 2:59-63 // Neh 7:61-65. These lists question the authenticity of claims to the land through emphasizing the importance of ancestral roots. Only those who can claim direct genealogical descent can forge an entitlement to the land. As such the sons of the priests whose genealogy was not found are treated as though they are defiled (גאל). This brief narrative taps into an important aspect of roots return: the role of the ancestors. One important aspect about claims to the land, and indeed about emotional attachment to the land, is the perceived link between those who return, the land itself, and the land's connection to the ancestors. This issue has recently been explored in detail with regard to anthropological theory relating to burial. As Stavrakopoulou argues, 'Persian-period incomers ... appropriated traditional land-claiming strategies, thus "indigenizing" themselves by textually re-mapping and re-placing the ancestral dead'. ${ }^{27}$ As such, ideas about the territorial dead play a serious role in forging connections with the land. However, the material relating to the idea of roots return reveals another dimension to this link with the land. Not only is it a connection on a political and social level, it is also an emotionally important connection. Ancestors are not simply used to stake a claim in the land, they form part of a larger network of ideas about ethnic identity. As such, making claims to connection with the land through ancestors reveals what Blunt refers to as grounded attachment. Although the results of such ideas about return to, and bonds with, the land are open to manipulation (especially if such ideas are challenged by a perceived ethnic Other on the land), the degree of emotional attachment to the land through ancestors is nevertheless a powerful motivating factor for return, and one which is not necessarily intentionally exclusive from the outset.

26 Alison Blunt, 'Cultural Geographies of Migration: Mobility, Transnationality and Diaspora', Progress in Human Geography 31 (2007): 684-694 (687).

27 Francesca Stavrakopoulou, Land of Our Fathers: The Roles of Ancestor Veneration in Biblical Land Claims (LHBOTS 473; New York / London: T\&T Clark, 2010), 136. 
A narrative which illustrates the concept of grounded attachment effectively is that of Jacob's death (Gen 47:29-31).

\author{
bury me not (קבר), please, in Egypt: \\ But I will lie (שכב) with my fathers, \\ and thou shalt carry me out of Egypt, \\ and bury me (קבר) in their burying place (Gen 47:30c-31).
}

Jacob's request that he is buried back in the land is particularly interesting. If some degree of parallelism can be assumed, then the aged plea of the dying man appears to conceptualize burial as unification with the ancestors since the verbs 'bury' and 'lie with' both appear in the second stich. The verb שכב is particularly revealing, usually referring to the death and burial of kings (1 Kgs 2:10; 11:43; $14: 20,31 ; 15: 8,24 ; 16: 6,28)$. Just as a royal line is not broken, so too the narrator suggests that a grounded attachment to the land through ancestral inheritance should not be broken.

If we assume that among those who returned to Yehud, there may have been second- or third-generation individuals who underwent ancestral return migration, then these observations are particularly interesting. Ezra's intermarriage incident is introduced using terminology which explicitly connects the community with the land through what might be termed 'roots metaphors'. The introductory self-ascription of those who returned from the exile, the בני הגולה, is the 'Holy Seed' (זרע הקדש; Ezra 9:2). Moreover, it is reported that the Holy Seed have 'intermingled' (התערב) a metaphoric expression of intermarriage (התחתן) with the 'people of the land' (Ezra 9:2). Of course, it is clear that at this point, the semantic range of the noun 'seed' is being exploited in quite a sophisticated manner to give the metaphoric self-ascription multivalent levels of significance. However, the implication is clear: holy seed and holy soil belong together, or put another way, bad seed will pollute good soil. That is to say, the presence of the ironically named - since it implies possession - 'people of the land' on the land itself defiles the land. This sentiment is especially clear through the powerfully derogatory statement of Ezra 9:11:

The land you are entering to possess is a land polluted (ארץ נדה) by the corruption (נדה) of its peoples. By their detestable practices (בתועבתיהם) they have filled it with their impurity (בטמאתם) from one end to the other.

Much has been written about this statement, especially with regard to the purity terminology. However, against the context of second and third-generation ancestral return migration, it is especially interesting. We noted how the homeland becomes a sort of mythical place, and how this myth manifests itself in terms 
of survival narratives and roots metaphors which can be used coercively. When viewed from this perspective the conceptual link between the land and the seed becomes a rallying cry for justifying the Holy Seed's existence on the land, and for denigrating the so-called people of the land in terms of their rights to remain living there. Thus, the author depicts a world where those who have claims to the land are those who can claim ancestral inheritance, rather than those who live there.

A trend reported by many second- and third-generation return migrants, or ancestral return migrants, is the experience of a hybridized identity. In many ways this is a more extreme version of the 'foreign homeland' experienced by returning migrants, just with the additional complication that the "homeland" was always an imagined placed, constructed by parents and grandparents who experienced exile. Since diasporas partake in a 'triangular' relationship with the host society and the homeland it is not surprising that notions of 'home' and 'belonging' for the later generation are likely to be highly ambiguous and multi-layered. ${ }^{28}$ King and Christou illustrate how for the second generation, the search for 'belonging' and 'home' is often an extremely powerful, emotional, and even life-changing experience through using the example of Greek-Americans returning to Greece. For these ancestral return migrants, the search for the homeland is 'also a search for ontological security from a world which is otherwise confusing or perceived as moving too fast or in the wrong direction'. ${ }^{29}$ That is to say, the second and third-generations may be understood as searching for a final 'resting place' in order to ease the cognitive dissonance, or existential anxiety of half-belonging/ not belonging. In many ways such an emotion is comparable to the 'homeland myth' among first-generation returning exiles. ${ }^{30}$ In both cases, the 'return' is a loaded nexus of ideas orbiting around an imagined stability and coherence, that is, an attempt to relocate an identity which has been dislocated by experience of exile (or the parents' and grandparents' experiences of exile). This experience is illustrated most profoundly in the case studies by Potter and Phillips concerning people who are casually referred to as 'Bajan-Brits' ${ }^{31}$ The studies illustrated that some Bajan-Brits felt that they did not 'belong' anywhere. As a consequence, they expressed their status of living in the plural world of their parents' origin, after

28 William Safran, 'Diasporas in Modern Societies: Myths of Homeland and Return', Diaspora 1/1 (1991): 83-99.

29 King and Christou, Cultural Geographies, 16.

30 Southwood, Ethnicity, 48-49.

31 Robert B. Potter and Joan Phillips, “'Mad Dogs and International Migrants?” Bajan-Brit Second-Generation Migrants and Accusations of Madness', Annals of the Association of American Geographers 96 (2006): 586-600. 'Bajan' is a contraction referring to British citizens who were originally from Barbados or whose ancestors come from there. 
having been raised in the colonial 'mother country', as one of 'liminal, hybrid, and in-between positionality'. Thus, the complexity of identity for the second generations mirrors cross-cutting issues connected with ethnicity, class, and age. ${ }^{32}$

In light of these observations, the evidence suggesting a prolonged return movement from exile to postexilic Yehud is particularly significant. Many returnees were probably second-generation descendants. This adds a further level of significance to the self-ascription בני הגולה. In this case, the noun גולה is being used not only to refer to the sustained period of existence away from Yehud, but also to refer to the group who were initially exiled. The observation that ancestral return movements provoke the sense of being an 'outsider,' or of having a hybridized identity, is also interesting in light of the title. It is remarkable that throughout Ezra 9 and 10, the preferred expression of identity is 'Children of the Exile,' rather than 'Holy Seed' or 'Israel.' The paradoxical retention of this title while in the ancestral homeland could, at some level, be understood as a reflection of the on-going consciousness of being 'outsiders', alongside a boundarymarking, self-isolation device. When confronted with the cross-cutting issues of land ownership and tenure, class, and possibly, differences in religious practice, such problematic relationship with the so-called homeland could only have been exacerbated. Thus, as well as referring to a collective 'imagined diaspora', the term בני הגולה also functions as an assertion of ethnic kinship. The the only group who can claim authentically to be Israel since their ancestry can be traced to pre-exilic times, and as a consequence of this belief they, or at least our author, perceive the necessity for endogamous 'ethnic' barriers.

\section{Conclusions}

It is widely acknowledged that the exile was a traumatic event which had a powerful, long-standing, impact upon the religious and social dimensions of Yahwism. However, it must also be acknowledged that the return from exile was just as, if not more, of an ordeal for those who returned. Both events could have, and given the treatment of 'foreign women' within the text, clearly did give rise to a greater consciousness of ethnicity, of its boundaries, of its components, and of its instrumental utility for gaining land and influence. Yet, in light of the casestudies connected to return migration, it seems that the return from exile was potentially more devastating than the exile itself; the on-going emotional signifi-

32 Potter and Phillips, 'Mad dogs', 586-592. 
cance of the homeland and artificial preservation of the 'old homeland' could only have given rise to disappointment, an emotion all the more pronounced for the ancestral return migrants of later generations. In light of these observations, the simplistic application of the 'exile and return' paradigm which often occurs within scholarship should be dispensed with. Instead, what appears to be the case is a long-standing development of religious and ethnic identities in light of the prevailing complex social forces that often accompany migratory movements. The poignant and ironic consequences of modern return migration movements, which, as has been demonstrated, are that those who stayed in the homeland, now Yehud, are perceived, as ethnically and religiously foreign. That is to say, that although they may not be different in what we would term a 'racial' sense, the perception of ethnicity is nevertheless strong enough to manifest itself in the types of behaviours that accompany ethnic difference. As noted, in many ways, this observation brings us back to the challenge of defining and describing ethnicity. In light of the literature relating to the effects of return migration on ethnicity, it is likely that what we find within many accounts concerning return to the land in postexilic literature was more deep-seated than legitimization politics. What emerges is a greater recognition of the social significance of various migrations, even across the generations, which the group responsible for the text are a product of. The consequent sense of dislocation, most palpable through the expressions of diasporic identity, which emerged through returning to Yehud invoked the perception of foreignness. Likewise the sense of vulnerable ethnic identity provoked by such circumstances is likely to have played a pivotal role in the group's emphasis of boundaries and on authenticity. Therefore, ethnic differences progress from being perceived, to being created, and even exacerbated upon return to the homeland. 